\title{
The Development of Analytic Team Collaborative Learning Model Based on Brain-Based Learning (BBL) for Junior High School Science Learning in Agroecosystem Areas
}

\author{
Yolanda Leony Agustia Mertha ${ }^{1)}$, Imam Mudakir ${ }^{2)}$, Jekti Prihatin ${ }^{3)}$ \\ Faculty of Teacher Training and Education, University of Jember, Indonesia. \\ email: imam_mudakir@yahoo.com
}

\begin{abstract}
Students in the agroecosystem area are generally less active because the teacher does not utilize the potential of the surrounding agroecosystem. This can be overcome by applying Brain-Based Learning (BBL) approach combined with AT collaborative learning model. This study aimed to produce Analytic Team learning model based on Brain-Based Leaning (AT-BBL) that is valid, practical, and effective, and also improves the students' critical thinking skills and learning outcomes. This study used $R \& D$ with $4 D$ development model which only carried out three stages, namely define, design, and development without using the disseminate stage. The average validation is 86.98 (highly valid). The average percentage of teacher responses is $92.94 \%$, and the average percentage of student responses is $91.22 \%$ which is very practical.
\end{abstract}

\section{Keywords: Agroecosystem, BBL approach, Analytic Team Learning Model, Collaborative Learning}

\section{INTRODUCTION}

Agroecosystem refers to agriculture that is a reciprocal relationship between a group of people (society) and the physical environment of their environment to enable the survival of the society (community) (KBBI, 2002). The agroecosystem area is an agricultural ecosystem (cultivation of plants) according to its general meaning. Indonesia is an agrarian country, which means that the main source of income for Indonesian people comes from agriculture. The vast number of rice fields in Indonesia reached 8,087,393 hectares in 2015 (BPS, 2015). The number of farmers in the agricultural sector is also very large which was about 31,705,337 people (BPS, 2013).

Learning that uses the environment can use learning objects that are used as real experiences, able to observe directly, and students are able to do individual or group work. The environment in the school is a good source of learning (Juairiah, 2014). Therefore the potential of the agroecosystem environment around the school can be a great potential for the source of natural science learning in junior high school. During the learning process, the teacher has not maximized the full potential of the environment. Teachers tend to do lecturing and students work on worksheets that cause them passive and less motivated students (Hendarwati, 2013). This is certainly contrary to the 2013 curriculum reformation.

The demand of 2013 curriculum is to encourage students to use the ability to think logically, reflectively, and creatively. Learning reformation has been published in 2013 curriculum which requires a learning process that emphasizes on students (StudentCentered Learning). Brain-Based Learning is able to create an active and meaningful learning environment for students (Sagala, 2014).

Brain-Based Learning is a learning concept aiming to empower the potential of brain (Chamidiyah, 2015). BBL allows students to know their brain abilities and learning styles. Students who are able to recognize their learning styles that are in accordance with themselves will be able to explore the material content. Students will eventually be able to learning process according to their understanding. Students who are aware of their learning styles will improve their cognitive and be able to learn casually (Duman, 2010). The learning approach certainly needs to be supported by a

Bioedukasi Vol. XVII. No. 1 April 2019 
learning model that matches its characteristics.

One learning model that is able to support students to develop their brain potential is collaborative learning. Collaborative learning provides opportunities for students to lead to the success of learning activities. Collaborative learning involves activating students and minimizing differences between individuals as well as growing awareness of interacting socially with efforts to create meaningful learning (Lasidos dan Zulkifli, 2015).

Unfortunately, 2013 curriculum does not only emphasize on students' activity, but also on students' critical thinking skills. Therefore, in addition to making active learning, a learning model that is able to help students think critically is needed. One of them is Analytic Team collaborative learning model.

Analytic Team learning model that requires collaboration and individual work simultaneously where in one group students are divided into their respective roles in analyzing a problem. In addition, the Analytic Team model also creates critical analysis that will enhance critical thinking skills (Barkley, 2016). Therefore, based on the background above, the purpose of this study is to develop a valid, practical and effective AT-BBL collaborative learning model so that students are able to actively participate and improve their critical thinking skills in the agroecosystem area.

\section{RESEARCH METHOD}

\section{Types of Research}

The type of research used in this study is research and development. The purpose of development research is to develop the results of prototype products, and to obtain research methods in the design and product evaluation. The development model used was 4D development model proposed by Thiagrajan, Semmel, and Semme in 1974. This development consists of 4 stages namely Define, Design, Development, and Disseminate. However, in this study the disseminate stage was not carried out because this study was to create the AT-BBL model only.

\section{Place and Time of Research}

The study was conducted at the Biology Education Study Program, Jember University and Junior High School 8 Jember. The Research would be held on August 7, 2018 until October 15, 2018.

\section{Data Collection Method}

Data were obtained from validation sheets, teacher and student assessment needs, teacher and student response questionnaires, pre-test and post-test scores, LKS, critical thinking, documentation, observation, and interviews

\section{Data Analysis Technique}

\section{Validation of Product Learning Models}

Validation data analysis included the validation of research instruments, syllabus, lesson plans, and also the validation of the pre-test and post-test questions. The validation data was analyzed by using formula:

$$
\text { Validation }=\frac{\sum \text { obtained score }}{\sum \max \text { imum score }} \times 100
$$

The results of the analysis were then grouped according to the following categories:

Table 1. Criteria for validity of learning models

\begin{tabular}{cc}
\hline $\begin{array}{l}\text { Level of } \\
\text { Validity }\end{array}$ & Criteria of Validity \\
\hline $84 \leq \mathrm{x} \leq 100$ & Highly Valid \\
\hline $68 \leq \mathrm{x}<84$ & Valid \\
\hline $52 \leq \mathrm{x} \leq 68$ & Enough \\
\hline $36 \leq \mathrm{x} \leq 52$ & Less Valid \\
\hline $20 \leq \mathrm{x} \leq 36$ & Invalid \\
\hline
\end{tabular}

Practicality of Learning Models

The practicality of the learning model was obtained from the teacher and student response questionnaire given after the learning with the AT-BBL collaborative learning model done. Questionnaires were assessed with a 1-5 Likert scale and analyzed by using a formula:

$$
\text { Re spons }=\frac{\sum \text { obtained score }}{\sum \max \text { imum score }} \times 100
$$

The results of the analysis were then grouped according to the following categories: 
Table 2. Criteria for the practicality of the learning model

\begin{tabular}{cc}
\hline $\begin{array}{c}\text { Level of } \\
\text { Practicality }\end{array}$ & $\begin{array}{c}\text { Criteria of } \\
\text { Practicality }\end{array}$ \\
\hline $84 \leq \mathrm{x} \leq 100$ & Very Good \\
\hline $68 \leq \mathrm{x}<84$ & Good \\
\hline $52 \leq \mathrm{x} \leq 68$ & Enough \\
\hline $36 \leq \mathrm{x} \leq 52$ & Poor \\
\hline $20 \leq \mathrm{x} \leq 36$ & Very Poor \\
\hline
\end{tabular}

Effectiveness of Learning Models

The effectiveness of the learning model was obtained from cognitive learning outcomes from the pre-test and post-test. Besides, it was also obtained from the results of critical thinking LKS. Cognitive learning results were obtained from the value of $\mathrm{N}$ Gain $(\mathrm{g})$ by using a formula:

$$
\text { Normalized gain }<g>=\frac{S \text { post }-5 \text { pre }}{S \max -\text { pre }} \times 100
$$

Hake in Kagan, (2018)

The indexes obtained from these formulas were then grouped according to the following categories:

Table 3. Normalized Gain criteria (g)

\begin{tabular}{cc}
\hline $\begin{array}{c}\text { Level of Effectiveness } \\
\text { (Index) }\end{array}$ & $\begin{array}{c}\text { Criteria of } \\
\text { Efectiveness }\end{array}$ \\
\hline $\mathrm{g}>0,7$ & High \\
\hline $0,3<\mathrm{g}<0,7$ & Medium \\
\hline $\mathrm{g}<0,3$ & Low \\
\hline & Hake in Nissen, (2018)
\end{tabular}

Students' critical thinking skill were obtained from critical thinking LKS which consists of 4 indicators, namely making questions, analyzing problems, solving problems, and concluding. Scores were analyzed by using a formula:

$$
\text { Critical Thinking }=\frac{\sum \text { obtained score }}{\sum \max \text { imum score }} \times 100
$$

The values obtained were further grouped according to the following categories:

Table 4. Criteria for level of critical thinking ability

\begin{tabular}{cc}
\hline $\begin{array}{c}\text { Level of } \\
\text { Practicality }\end{array}$ & $\begin{array}{c}\text { Criteria of } \\
\text { Practicality }\end{array}$ \\
\hline $84 \leq \mathrm{x} \leq 100$ & Very High \\
\hline
\end{tabular}

\begin{tabular}{cc}
\hline $68 \leq x<84$ & High \\
\hline $52 \leq x \leq 68$ & Medium \\
\hline $36 \leq x \leq 52$ & Low \\
\hline $20 \leq x \leq 36$ & Very Low \\
\hline
\end{tabular}

\section{RESULTS AND DISCUSSION}

\section{The Process Results of Analytic Team Collaborative Learning Model Based on BBL Process}

4D development model carried out during the study was only implemented in 3 stages without Disseminate due to time and cost limitations. The first step is to define the five phases, namely the front-end analysis applied by distributing need assessment to the Jember science teacher MGMP, observation and interviews with VII B class of junior high school 8 Jember science teachers to find out what conditions in the field and problems faced by teachers and students.

The next phase is the analysis of students conducted to determine the abilities, characteristics, and students' learning outcomes in science. (Kurniawan, 2013). Data were obtained from the results of replications in the previous material (Magnitude and Derivatives), only 5 students whose grades were above the KKM. Data were also obtained from interviews and classroom observations. The third phase of the task analysis was carried out which of course is adjusted to the KD and learning material. ) LKS is a sheet containing assignments that must be done by students. LKS itself contains a collection of basic activities done by participants to understand the material being studied according to the selected indicators. LKS generally contains of instructions and steps to complete a task (Ernawati, 2017).

The next phase was concept analysis, employed to analyze the concepts that would be taught to students so that students would be easily understood. The KD chosen in this development was adapted to the environment of the agroecosystem around the school, which is the rice field area. The last phase of the define phase was the formulation of learning objectives. The formulated learning objectives must fulfill the $\mathrm{KD}$ as the minimum standard of ability possessed by students after the learning. 
The second stage of 4D model is design. This stage is a stage for designing devices needed in the learning model (Syahrir, 2016). The design phase consists of 3 phases. First, the benchmark reference test phase. This phase was conducted to select the tests to be conducted during the study. Tests compiled by formulating $\mathrm{KI}$ and $\mathrm{KD}$ in the selected learning material are on the subject of classification of living things (Kusumaningrum, 2015). The selected test was a cognitive learning test consisting of pre-test and post-test, as well as the ability to test students' critical thinking.

The next phase of the design phase was the media selection that would be used during the model development. The media selection was done to make the media used are appropriate and in accordance with the indicators, objectives, and character of the material being taught. The last phase of the design phase was the format selection. The format choice was the stage for determining the format of the learning model, so that the format chosen was adjusted to the characteristics, principles and syntax of learning development, namely AT-BBL collaborative learning model (Syah, 2016).

The last stage of 4D model was the develop stage. This stage aimed to produce a learning model that has been done a series of revisions on the critics and suggestions of experts and practitioners (Nurwahida, 2018). The development stage was the stage of validating the learning model and learning devices followed by revisions. The learning model was applied to small classes with 9 people which were then revised when there are deficiencies. Then, it was implemented in the large classes with 32 students.

\section{Validation of Analytic Team Learning Model Based on BBL}

Validation was obtained from research instruments and product development, namely the learning model guidebook, syllabus, lesson plan, and pre-test and post-test question. Validation was done to test a new product, which was assessed by experienced experts to evaluate the product (Arimadona, 2016). This validation was carried out by 2 development experts. They are a lecturer from
Jember University, and 1 expert user, a science teacher from junior high school 8 Jember.

Table 5. which shows the results of learning instrument validation gave the average results of the manual aspects of 93.33 with highly valid category, the content aspects of 86.67 with with highly valid category, and language aspects of 93.33 with highly valid category. The overall average was 92 with highly valid category. Therefore, the research instruments were feasible to be used in the research.

The next validation of product validation was the result of development, namely the learning model guidebook, syllabus, lesson plan, and pre-test and posttest questions. The results in Table 6. show that the average manual book validation results are 85.33 with highly valid categoriey, the results of the average validation of the learning syllabus show an average of 86 with highly valid categoriey. The average results of the RPP validation were 86.91 with highly valid category. Finally, the pre-test and posttest questions showed an average of 88.33 with a highly valid category. The overall results of product validation or learning devices show an average of 86.98 with a highly valid category so that it can be used for the research. 
Table 5. Data of Research Instruments Validation

\begin{tabular}{|c|c|c|c|c|}
\hline No & Review & Validators & Appraisal Results & Category \\
\hline \multirow{4}{*}{ I. } & \multirow{4}{*}{ Directions } & Expert 1 (lecturer) & 90 & Highly Valid \\
\hline & & Expert 2 (lecturer) & 90 & Highly Valid \\
\hline & & User (teacher) & 100 & Highly Valid \\
\hline & & Validation average & 93,33 & Highly Valid \\
\hline \multirow{4}{*}{ II. } & \multirow{4}{*}{ Content } & Expert 1 (lecturer) & 80 & Valid \\
\hline & & Expert 2 (lecturer) & 80 & Valid \\
\hline & & User (teacher) & 100 & Highly Valid \\
\hline & & Validation average & 85,33 & Highly Valid \\
\hline \multirow{4}{*}{ III. } & \multirow{4}{*}{ Language } & Expert 1 (lecturer) & 80 & Valid \\
\hline & & Expert 2 (lecturer) & 100 & Highly Valid \\
\hline & & User (teacher) & 100 & Highly Valid \\
\hline & & Validation average & 93,33 & Highly Valid \\
\hline \multicolumn{3}{|c|}{ The Average Percentage of Validators } & 92 & Highly Valid \\
\hline
\end{tabular}

Table 6. Data of Product Validation

\begin{tabular}{|c|c|c|c|c|}
\hline No. & Document & Validators & $\begin{array}{c}\text { Appraisal } \\
\text { Results } \\
\text { (Scores) }\end{array}$ & Category \\
\hline \multirow[t]{4}{*}{1.} & \multirow{4}{*}{$\begin{array}{l}\text { Learning } \\
\text { Model } \\
\text { Guidebook }\end{array}$} & Expert 1 (lecturer) & 75,20 & Valid \\
\hline & & Expert 2 (lecturer) & 88 & Highly Valid \\
\hline & & User (teacher) & 92,80 & Highly Valid \\
\hline & & Validation average & 85,33 & Highly Valid \\
\hline \multirow[t]{4}{*}{2.} & \multirow[t]{4}{*}{ Syllabus } & Expert 1 (lecturer) & 78 & Valid \\
\hline & & Expert 2 (lecturer) & 86 & Highly Valid \\
\hline & & User (teacher) & 94 & Highly Valid \\
\hline & & Validation average & 86 & Highly Valid \\
\hline \multirow[t]{4}{*}{3.} & \multirow[t]{4}{*}{ Lesson Plan } & Expert 1 (lecturer) & 82,22 & Valid \\
\hline & & Expert 2 (lecturer) & 85,18 & Highly Valid \\
\hline & & User (teacher) & 93,33 & Highly Valid \\
\hline & & Validation average & 86,91 & Highly Valid \\
\hline \multirow[t]{4}{*}{4.} & \multirow{4}{*}{$\begin{array}{l}\text { Pre-Test and } \\
\text { Post-Test } \\
\text { Questions }\end{array}$} & Expert 1 (lecturer) & 90 & Highly Valid \\
\hline & & Expert 2 (lecturer) & 80 & Valid \\
\hline & & User (teacher) & 95 & Highly Valid \\
\hline & & Validation average & 88,33 & Highly Valid \\
\hline \multicolumn{3}{|c|}{ The Average Percentage of Validators } & 86,64 & Highly Valid \\
\hline
\end{tabular}




\section{Practicality of Analytic Team Learning Model Based on BBL}

The practicality of the learning model was obtained from teacher and student response questionnaire data given after the study was conducted. Questionnaires were filled by choosing a 1-5 Likert scale which was then analyzed and categorized in the practicality criteria of the learning model.

Based on the results of the teacher's response questionnaire in Table 7., the results show that the clarity indicator for the use of RPP is $90 \%$ with a very good category. The second indicator is the achievement of competencies and learning objectives obtained with the result of $96 \%$ with a very good category. The third indicator is student responses with the result of $86.67 \%$ with a very good category. The fourth indicator of the level of implementation difficulties shows $93.33 \%$ with a very good category.
The last indicator, the adequacy of time with $100 \%$ results with a very good category. The average of the response questionnaires was $92.94 \%$ included in a very good category.

The next analysis of student response questionnaires is in Table 8 . The results obtained on the first indicator, namely interest in learning showed an average score of $89.2 \%$ which was included in the excellent category. The next indicator is the usefulness of learning, showing the average of 32 students giving a response of $90.7 \%$. The last indicator is the interest in following learning, 32 students were obtained an average of $93.75 \%$ with very good indicators. The overall value of the three indicators from 32 students was $91.22 \%$ which was included in the excellent category. These results indicate that the ATBBL collaborative learning model is practically used in the learning process.

Tabel 7. Data of Teacher Responses

\begin{tabular}{clcc}
\hline No. & \multicolumn{1}{c}{ Indicator } & $\begin{array}{c}\text { Appraisal Average } \\
(\mathbf{\%})\end{array}$ & Category \\
\hline 1. & $\begin{array}{l}\text { Clarity of instruction for using lesson } \\
\text { plan }\end{array}$ & 90 & Very Good \\
\hline 2. & $\begin{array}{l}\text { Achievement of competence } \\
\text { learning objectives }\end{array}$ & 96 & Very Good \\
\hline 3. & Students responses & 85,33 & Very Good \\
\hline 4. & Level of diffuculty implementaion & 93,33 & Very Good \\
\hline 5. & Sufficient time & 100 & Very Good \\
\hline & Average of Teacher Responses & $\mathbf{9 2 , 9 4 \%}$ & \\
\hline \multicolumn{2}{c}{ Average Category } & Very Good & \\
\hline
\end{tabular}

Tabel 8. Data of Students Responses

\begin{tabular}{|c|c|c|c|}
\hline No. & Indicator & $\begin{array}{c}\text { Appraisal Average } \\
(\%)\end{array}$ & Category \\
\hline 1. & Interest in learning & 89,2 & Very Good \\
\hline 2. & Learning usability & 90,7 & Very Good \\
\hline 3. & Interest in following learning & 93,75 & Very Good \\
\hline & Average of Teacher Responses & $91,22 \%$ & \\
\hline & Average Category & Very Good & \\
\hline
\end{tabular}




\section{Effectiveness of Analytic Team Learning Model Based on BBL}

The effectiveness if learning model develop, obtained from the results cognitif test (pre-test and post-test) and also from the results of critical thinking skills during four major classes. The effectiveness of cognitive learning outcomes from the values of pre-test and post-test, which then analyzed using Normalized Gain (N-Gain). Results of the analysis showed in table 9. The results in table 9. Show, the average before treatment is 38,91 . After treatment is 74,16 . The average Normalized Gain is 0,58 (medium category). This means, there is an increase in students learning outcomes as long as AT-BBL collaborative learning applied. This is because pleasant learning makes students happier to follow the learning process. Interesting and fun learning will make students more enthusiastic in learning (Kristin, 2016).

In addition, students are ensured that their nutritional intake is fulfilled during the learning process. Students must be sure to have breakfast before attending the study. This is because breakfast provides an energy supply of glucose to the brain where glucose is very important to students' cognitive power, but unfortunately neurons cannot store glucose so the brain depends on blood flow to get energy from glucose (Khalida, 2015)

Brain gym activities also help in achieving learning outcomes. Movements in the Brain gym involving the hands and feet are able to provide stimulus stimulation to the brain so that it can improve cognitive abilities, movements in the Brain gym can facilitate the blood flow and stretch the muscles (Fajriati, 2017).

Giving classical music to students also affects student learning outcomes where students will concentrate more. Gumanti (2018) states that classical music is capable of producing alpha waves which can stimulate the limbic system in brain neuron tissue, so as to improve memory, visual, and motor concentration.

The important thing that can improve student learning outcomes is the heterogeneous process of student collaboration during learning. Heterogeneous groups make students able to hold discussions with group members around them, so that discussions can take place through the process of exchanging ideas.

Students will be centered on their respective roles and duties, but still hold discussions because the assignments and roles given are related to each other so students also see how the group members perceive them around. The effectiveness of the learning model can also be seen from students' critical thinking skills in Table 10. The results of critical thinking skills are obtained from the critical thinking LKS values given for four large classes. The results in Table 10. It can be seen that the first large class, obtained an average of 80.22 which is included in the high category, the second large class had an average of 80.53 included in the high category, the third large class with an average of 74,59 was included in the high category, and finally the fourth large class with an average of 76.53 was also included in the high category.

Tabel 8. Data of Students Cognitive Learning Outcomes

\begin{tabular}{|c|c|c|c|c|c|}
\hline & & $\begin{array}{c}\text { Amount of } \\
\text { Students }\end{array}$ & Average & $\begin{array}{c}\text { Normalized gain } \\
\text { Average }\end{array}$ & Category \\
\hline Major Class & Pre-test & 32 & 38,94 & \multirow{2}{*}{0,58} & \multirow{2}{*}{ Medium } \\
\hline Trial & Post-test & 32 & 74,16 & & \\
\hline
\end{tabular}


Tabel 8. Data of Students Cognitive Learning Outcomes

\begin{tabular}{cccc}
\hline Major Class Trial & $\begin{array}{c}\text { Amount of } \\
\text { Students }\end{array}$ & Average & Category \\
\hline $\mathbf{1}$ & 32 & 80,44 & High \\
\hline $\mathbf{2}$ & 32 & 80,53 & High \\
\hline $\mathbf{3}$ & 32 & 74,59 & High \\
\hline $\mathbf{4}$ & 32 & 76,53 & High \\
\hline The Average of Crittical Thinking \\
Skills
\end{tabular}

The results of critical thinking skills of the four large classes indicate that the average students' critical thinking skills of 78.02 belong to the high category.

These results are according to Hajar (2016), that Analytic Team collaborative learning is a learning model that requires analysis and makes students think critically. This result is also in accordance with the research conducted by Nahdi (2015), where brain-based learning can improve students' critical thinking skills compared to conventional learning.

The results of effectiveness obtained from the analysis of normalized gain of student learning outcomes in the pre-test and post-test and students' critical thinking skills indicate that the AT-BBL collaborative learning model is in a good category. So that the ATBBL collaborative learning model is effective and qualifies to be a good learning model.

The learning model meets the requirements of valid, practical, and effective so that it can be said to be a good learning model. This learning model is then expected to be used as one of the models that supports 2013 curriculum which is based on the $21^{\text {st }}$ century learning.

\section{CONCLUSION}

The development of the AT-BBL collaborative learning model has met the requirements of a good learning model, which is valid, practical, and effective. Validity is obtained from the validation of the research instrument and learning tools. The mean validation of the research instrument of 92 was included in the very valid category, while the mean validation of the learning device was 86.98 included in the very valid category. So, the AT-BBL collaborative learning model is valid and can be used during learning. The practicality of the AT-BBL collaborative learning model is known from the teacher response questionnaire analysis with an average of $92.94 \%$ with a very good category. Student questionnaire response analysis showed an average of $91.22 \%$ in the very good category so that the practical AT-BBL collaborative learning model was used in learning. The effectiveness of AT-BBL collaborative learning is known from the results of cognitive learning and critical thinking skills. Cognitive learning outcomes showed an increase in average from 38.94 to 74.16 so that there was an increase in student learning outcomes. The learning outcomes of the pre-test and post-test are then analyzed by $\mathrm{N}$-Gain, indicating an index of 0.58 which is included in the medium category. The results of students' critical thinking skills showed an average of 78.02 which was included in the high category. This shows that the AT-BBL collaborative learning model can make students think critically which means that the AT-BBL collaborative learning model is effective to be used in learning.

\section{REFERENCES}

Arimadona, S. 2016. Pengembangan Modul Pembelajaran Biologi Berbasis Integrasi Islam Sains. Jurnal Pendidikan Rokania. 1 (2).

Barkley, E.E., K.P. Cross, dan C.H. Major. 2016. Collaborative Learning Techniques. Bandung: Penerbit Nusa Media. 
Chamidiyah. 2015. Pembelajaran melalui Brain-Based Learning Dalam Pendidikan Anak Usia Dini. Edukasia: Jurnal Penelitian Pendidikan Islam. 10(2): 279300.

Duman, B. 2010. The Effects of Brain Based Leaning on the Academic Achievemnt of Students with Different Learning Style.Jornal of Educational Sciense. (10) 4: 2077 - 2103.

Ernawati, A., M.M. Ibrahim, dan A. Afif. 2017. Pengembangan Lembar Kerja Siswa berbasis Multiple Intellegences pada Pokok Bahasan Substansi Genetika Kelas XII IPA SMA Negeri 16 Makassar. Jurnal Biotek. 5 (2).

Fajriati, I.S., Safei, dan Saprin. 2017. Pengaruh Penerapan Metode Pembelajaran Brain-Based Learning Berbantuan Brain Gym terhadap Hasil Belajar Peserta Didik. Jurnal Biotek. 5 (1).

Hajar, M.U, J. Prihatin, dan M. Iqbal. 2016. Pengaruh Pembelajaran Kolaboratif Tipe Analytic Team Melalui Lesson Study Terhadap Hasil Belajar Siswa. Prosiding Seminar Nasional II Tahun 2016. Malang, 26 Maret 2016.

Hendarwati. E. 2013. Pengaruh Pemanfaatan Lingkungan sebagai Sumber Belajar melalui Metode Inkuiri terhadap Hasil Belajar Siswa SDN I Sribit Delanggu pada Pelajaran IPS. Pedagogia. 2(1): 5970.

Juairiah, Y., dan Djufri. 2014. Pembelajaran Berbasis Lingkungan untuk Meningkatkan Hasil Belajar Siswa pada Konsep Keanekaragaman Spermatophyta. Jurnal Biologi Edukasi. 6(3): 83-88

Kamus Besar Bahasa Indonesia. 2002. Jakarta: Balai Pustaka.

Kagan, Mc Sam., E. Sayre, dan A. Madsen. 2017. Normalized gain: What is it and when and how should I do? https://www.physport.org/recommendatio
ns/Entry.cfm?ID=93334 [diakses pada tanggal 30 Agustus 2018].

Khalida, E., E. Fadlyana, dan D.H. Somasetia. 2015. Hubungan Kebiasaan Sarapan dengan Prestasi Belajar dan Fungsi Kognitif pada Anak Sekolah Dasar. Sari Pediatri. 17 (2).

Kristin, F. 2016. Efektivitas Model Pembelajaran Kooperatif Tipe STAD Ditinjau dari Hasil Belajar IPS Siswa Kelas 4 SD. Scholaria. 6 (2).

Kurniawan, A.D. dan L. Nurlaela. 2013. Pengembangan Buku Siswa untuk Meningkatkan Proses dan Hasil Belajar Kompetensi Dasar Cornflake Cookies pada Siswa Tunagrahita SMA-LB Negeri Gedangan, Sidoarjo. E-Journal Boga. 2 (1).

Kusumaningrum, N.A. 2015. Pengembangan Modul Identifikasi Insekta di BKPH Kedunggalar Kecamatan Pitu Ngawi pada Mata Kuliah Taksonomi Hewan Invertebrata. Florea. 2 (2).

Lasidos, P.A., dan Z. Matondang. 2015. Penerapan Model Pembelajaran Kolaboratif untuk Meningkatkan Aktivitas dan Hasil Belajar Rencana Anggaran Biaya Siswa Kelas XII Kompetensi Keahlian Teknik Gambar Bangunan SMKN 2 Siatas Barita Tapanuli Utara. Jurnal Educational Building. 1(1): 13-22.

Nahdi, D.S. 2015. Meningkatkan Kemampuan Berpikir Kritis dan Penalaran Matematis Siswa melalui Model Brain-Based Learning. Jurnal Cakrawala Pendas. 1 (1).I

Nissen, J.M., R.M. Talbot, A.N. Thomson, dan B.V. Dusen. 2018. A Comparison of Normalized Gain and Cohen's $d$ for Analyzing Gains on Concept Inventories. https://arxiv.org [diakses pada 10 Agustus 2018]

Nurwahida, M. Danial, dan Mansyur. 2018. Pengembangan Perangkat Pembelajaran

Bioedukasi Vol. XVII. No. 1 April 2019 
Kimia Berbasis Discovery Learning pada Materi Larutan Penyangga di Kelas XI

SMA. Chemistry Education Review. 2

(1).

Sagala, P.N. 2014. Penerapan Metode Brain Based Learning Pada Mata Kuliah Sebagai Upaya Meningkatkan Komunikasi Matematis Dan Ketrampilan Berpikir Tingkat Tinggi Mahasiswa. Jurnal Tarbiyah. 21(1). 52-74.

Syah, A.I., 2016. Pengembangan Perangkat Pembelajaran Langsung Berbasis Pendekatan Kontekstual dalam Materi Asam Basa Garam di Kelas VII SMP Negeri 25 Bulukumba. Jurnal Pinisi Research. 6 (2).

Syahrir. 2016. Pengembangan Perangkat Pembelajaran Matematika SMP untuk Meningkatkan Kemampuan Berpikir Kreatif. JIME. 2 (1).

Widiana, I W., G.W. Bayu, dan I.N.L. Jayata. 2017. Pembelajaran Berbasis Otak (Brain-Based Learning), Gaya Kognitif Kemampuan Berpikir Kreatif dan Hasil Belajar Mahasiswa. Jurnal Pendidikan Indonesia. 6 (1). 